\title{
Looking for the sectoral interdependence: evidence from the Visegrad countries and China
}

\author{
Ewa Cieślik ${ }^{1}$ (D) \\ Published online: 19 March 2019 \\ (c) The Author(s) 2019
}

\begin{abstract}
This article presents the Visegrad Group (V4) member countries with special focus on the role of these countries in international trade relations with China, especially global value chains (GVCs) in terms of selected sectors. We have chosen five sectors: manufacture of motor vehicles, trailers and semi-trailers; manufacture of computer, electronic and optical products; mining and quarrying; basic metals and fabricated metal products; and manufacture of electrical equipment. The goal of this paper is to analyse the role of China in the V4 states' gross exports and vice versa in selected sectors. We verified two hypotheses: (1) the V4 countries have deteriorated their positions in GVCs in relation to China in selected sectors recently; (2) the V4 states have become more dependent on Chinese value added embodied in their gross exports of selected sectors, but the opposite trend has not been observed. To achieve the aim of this study we investigated on the sectoral links between China and the V4 countries.
\end{abstract}

Keywords Global value chains $\cdot$ V4 $\cdot$ China $\cdot$ Sectoral production linkages

JEL Classification $\mathrm{C} 1 \cdot \mathrm{F} 1 \cdot \mathrm{F} 5 \cdot \mathrm{O} 1$

\section{Introduction}

Since the early 1990s, the Visegrad Group (V4) member countries (the Czech Republic, Hungary, Poland and Slovakia) has undergone transformations in many dimensions. One of the transformation priorities was the reorientation of foreign trade to the Western Europe first (Brada 1991; Arghyrou 2000; Augier et al. 2005; Rynarzewski 2013; Cieślik et al. 2016) and recently to China.

When the Chinese President announced introduction and to some extend reactivation of the Silk Road under the names New Silk Road or One Belt One Road (OBOR), no one expected that this initiative might unite so many countries. The V4 states have also become an important part of this strategy, due to strategic geographical location of its member countries. Analyzing the current international situation and a growing role of China in the world economy, the V4 states should strengthen the cooperation in many dimensions

Ewa Cieślik

ewa.cieslik@ue.poznan.pl

1 Poznan University of Economics and Business, Poznan, Poland 
(Cieślik 2017). When in 2011 China launched a new forum for cooperation with the Central and Eastern European countries (called ' $16+1$ '), the relations among the V4 and China entered a new chapter of pragmatic cooperation (Deng and Liu 2018). On the one hand China has intensified its outward direct investment in the V4 region as well as exports. In 2000-2015, Hungary attracted the largest part of foreign direct investment (FDI) in Central and Eastern Europe (53\%), followed by Romania (20\%), and Poland (12\%). In terms of China's exports, Poland and the Czech Republic were the leaders (Szunomar and McCaleb 2018; UNCTAD 2019). On the other hand, the V4 countries have become more and more depended on the production linkages with Chinese firms.

With regards to the fact, that the V4 are covered by Chinese OBOR strategy, the aim of this article is to analyse the role these states play in GVCs and evaluation of connections between the V4 states and China in five selected sectors. To ensure consistency and comparability of study results, the data sources were databases kept by OECD/WTO Trade in Value Added Database till 2014.

In our article we verify two hypotheses: (1) the V4 countries have deteriorated their positions in GVCs in relation to China in selected sectors recently; (2) the V4 states have become more dependent on Chinese value added embodied in their gross exports of selected sectors, but the opposite tendency has not been observed.

The article consists of four sections. Firstly, it discusses the role of the V4 states in GVCs in the light of the literature. Then we introduced the short research methodology description. The third section analyses China and the V4 countries in terms of paths of participation in GVCs using sector-level approach. The last section consists of conclusions.

\section{A literature review}

The global economy is increasingly determined by GVCs characterized by growing shares of international trade, global GDP and employment (Bair 2008; Crang et al. 2013; Pomfert and Sourdin 2017; Buckley 2018). Because a 'value chain' is generally understood as trade involving internationally organized production processes (Stöllinger et al. 2018), it naturally encompasses a wide array of activities undertaken by firms and workers to bring a product from its conception to end use and beyond, such as research and development (R\&D), design, production, marketing, distribution and support to the final consumer. As all activities take place within a global network, the GVC framework seems useful for finding out about the extent to which business decisions affect the trajectory of economic and social "upgrading" or "downgrading" in countries and regions. It is also notable that the evolution of GVCs in various sectors (commodities, apparel, electronics, tourism and the outsourcing of business services) has an increasing effect on global trade, employment and production, as well as on how firms, producers and workers in developing countries join in the global economy (Gereffi and Fernandez-Stark 2016). For many countries, particularly those with lower income levels, the possibility of entering GVCs is a major factor in their development. As important as participation in the global exchange of goods and services is the ability to develop strategies capable of ensuring the highest possible levels of growth and economic development while reducing unemployment and poverty rates (Gereffi et al. 2005; Gereffi 2014).

A notable feature of GVCs is that they differ between regions. The importance of GVCs and considerable fragmentation of trade is especially observed in North America, East Asia and Europe (mainly in the US, Japan, Korea, China, Brazil, Russia, India and Switzerland; see Stöllinger et al. 2018). However, as more and more attention is 
being given to the regional aspect of GVCs, Johnson and Noguera (2012), among others, have proposed that in some cases regional value chains (RVGs) should be considered instead of GVCs. An especially interesting subject seems to be post-socialist countries in Europe that between the end of World War II and the late 1980s were the central command economies largely immune to the impacts of globalization. The political and economic transition that they initiated in the early 1990s earned them EU membership in the mid-first decade of the $21 \mathrm{st} \mathrm{c}$. This means that they have been free-market economies interacting with the global business environment for only (around) 25 years.

Hence, the Central and Eastern European countries including the V4 states are going to be more and more heavily involved in the process of global production. Much empirical research demonstrates the close and dynamic integration of the region with the EU market (especially the euro area) and in a more limited scope with the global economy as well (Nilsson 2000; Kangas and Niskanen 2003; Kandogan 2005; Behar and Frend 2011; Altomonte et al. 2012; Amador et al. 2013; Bjelić et al. 2013). Moreover, the V4 states were more specialized in the labor-intensive and resource-intensive sectors of manufacturing by using their comparative advantages (Dobrinsky 1995). This specialization is the effect of higher FDI inflows and trade in the sector (intra-industry trade).

More detailed surveys that focus on selected sectors of V4 economies can be found. Stehrer and Stöllinger (2015) studied potential factors that limited or encourage the economic integration of the manufacturing sector. They assumed that Germany to be the 'anchor' of the Central and Eastern European supply chain, Kaminski and Ng (2001, 2005) investigated the trade networks. They emphasized that the growth of specialization in manufacturing was an important driver of the economic growth of many V4 states. They argued that these production linkages underwent a significant transition: a shift from labour-intensive simple assembly operations to processing and local production of parts and an expansion beyond the EU markets. Moreover, they presented the integration of Central and Eastern European countries into the EU production networks in three sectors: (a) furniture, (b) automotive sector and (c) sectors experiencing the 'information revolution'. They proved that transformation in the furniture sector was observed in all the economies analysed. The same changes within car industry were noticed Hungary experienced integration into the EU production network within sectors based on the 'information revolution'. Similar results were presented by Timmer et al. (2012). They analysed nations specialising mainly in electronics (Hungary, Slovakia), machinery (the Czech Republic, Slovakia) and transport equipment (all V4 states) and demonstrated that the V4 states significantly increased their proportion of income from participation in GVCs in Europe (from 4.4\% in 1995 to $9.3 \%$ in 2008), with a continuous growth in the number of high-skilled workers involved in production processes (see also Pavlinek 2005; Jürgens and Krzywdzinski 2009). Egger and Egger (2005) proved that processing foreign trade in the EU increased in 1988-1999, in particular with Central and Eastern European countries. Marin (2006) analysed data on FDI of German and Austrian corporations in Eastern Europe in 1990-2001. He documented the pattern of intra-firm trade and the emergence of some of the Eastern European states as new players in the GVCs. In turn, Simkova (2013) pointed out the sectors in Central and Eastern European states which were on the whole integrated into GVCs. In addition to the car industry (almost all analysed nations), were electrical engineering (Poland, Slovakia) and mechanical engineering (Poland, Czech Republic) (see also Akbar and Ferencikova 2007; De Simone 2008). Baldone et al. (2001) analysed the textile and apparel industry and proved that outward processing trade represented a significant share of trade between the EU-15 and Central Europe in this sector. Later, the same authors (Baldone et al. 2007) observed that the EU processing trade tends to be concentrated in a few industries and 
regions. Helg and Tajoli (2005) comparing Germany and Italy, observed that Germany has a higher propensity to use outward processing trade than Italy in a few specific sectors, especially when we take into account Central and Eastern Europe.

The turning point in the development of GVCs relation was the world economic crisis started in 2008. Sass and Szalavetz (2013) examined the effects of the crisis on GVC for integrated Hungarian car and electronic industries. According to their results companies have had functional upgrading effects as an effect of the global crisis and the reorganisation of corporations. The global crisis induced certain positive effects on GVCs in the V4 states. The Authors of 'Global value chain report 2007' observed similar findings (IBRD and WTO 2017). Stöllinger et al. (2018) proved that one important reason why the EU-28 as a whole suffered a relatively modest loss in world market share in value chain trade is the performance of the new EU members, including the V4 states. The Central and Eastern European countries, as a whole, doubled their share in EUwide value chains exports between 2000 and 2014 (from approx. 5-11.6\%). Moreover, when we consider international value chains (GVCs as well as RVCs) many of these states should be perceived as 'offshore' destinations with the resulting foreign trade flows from the 'offshoring' activities being dominated by value added originating from the investor countries. The tendency observed in the V4 states showed that these states were also successful in participating with their domestic value added embodied in partners' gross exports in such transactions. In turn, Foster et al. (2013) estimated that the domestic value added embodied in gross exports was relatively low in the Czech Republic and Hungary, but the degree of vertical specialisation was quite high in these states.

There have been only a few studies concentrating on relations between Central and Eastern Europe (including the V4 states) and China so far. Chen (2012), Kong (2013, 2014), Cieślik (2014, 2017) and Matura (2017) focused on the trade and investment relations, not mentioning value added linkages. Szunomár (2014) presents Chinese FDI in the V4 countries before and after the crisis. Whereas early participation in a GVCs focused mainly on assembly operations, increasingly tasks of higher complexity are being performed and the V4 states have become important suppliers of final products and parts. Fung et al. (2009) investigated the complicated and not obvious relationships between Chinese FDI and inward FDI in Central and Eastern Europe. Tuszynski (2015) described the Polish role in the Central and Eastern Europe-China cooperation touching Chinese FDI and foreign trade. Éltető and Toporowski (2013) gave detailed analysis of the trade between the V4 countries and Asian countries (including China). Similar, Ando and Kimura (2013) presented the trade and production connections between Asia and Europe via the V4 states in the past 15 years.

According to numerous studies (Fortwengel 2011; Jacoby 2010), the V4 states were found in relatively downstream activities of global production chains. Acquired technology, capital and know-how have underpinned the expansion and competitiveness of their exports. Hence, they do not have an obvious specialisation in regard to labor-intensive or low-skill undertakings. Climbing the GVC into knowledge-intensive production have been their prime concern. Damijan et al. (2013) argued that although inflows of FDI contributed to the changes in exports structures of Central and Eastern European states, there were still visible differences among analysed stated. The „core” countries (which are the V4) increased more advanced exports while the others concentrated more on lower technology export flows. They tried to explain that situation by the different degree of integration into the GVCs. Nevertheless, we should be aware that Central and Eastern European states, including the V4 countries, have experienced extremely strong competition from Asian countries, especially China, that have been determined to rise up in knowledge-intensive manufacturing and the manufacturing GVC (Song 2017). 


\section{Methodology}

In order to analyze the transformation of foreign trade in the V4 states and to follow their paths of participation in GVCs we employed the methodology described more precisely in another paper (Cieślik et al. 2016). Generally, among the many measures we decided to use a multi-regional IO model, which is a combination of approaches introduced by Hummels et al. (2001), Johnson and Noguera (2012), Timmer et al. (2012) and Koopman et al. (2014).

We state that we have $\mathrm{S}$ sectors and $\mathrm{N}$ countries. Each sector in one country produces a single differentiated product: SN goods. Production (x) is used for both, to satisfy final demand (y) and to production of intermediate input $(\mathrm{z})$ in production process (at home country and abroad):

$$
\mathrm{X}_{\mathrm{i}}(\mathrm{s})=\Sigma_{\mathrm{j}} \mathrm{y}_{\mathrm{ij}}(\mathrm{s})+\Sigma_{\mathrm{j}} \Sigma \mathrm{tz}_{\mathrm{ij}}(\mathrm{s}, \mathrm{t})
$$

where we define the coefficients matrix A as a matrix with SNxSN dimension, where elements

$$
\mathrm{a}_{\mathrm{ij}}(\mathrm{s}, \mathrm{t})=\mathrm{z}_{\mathrm{ij}}(\mathrm{s}, \mathrm{t}) / \mathrm{x}_{\mathrm{j}}(\mathrm{t})
$$

we can reformulate $(1)$ as $\mathrm{x}=\mathrm{Ax}+\mathrm{y}$.

Thus we may formulate a fundamental condition

$$
\mathrm{x}=(\mathrm{I}-\mathrm{A})^{-1} \mathrm{y}
$$

This can be presented as a matrix:

$$
\left[\begin{array}{c}
X_{1} \\
\vdots \\
X_{N}
\end{array}\right]=\left[\begin{array}{ccc}
I-A_{11} & \cdots & -A_{1 N} \\
\vdots & \ddots & \vdots \\
-A_{N 1} & \cdots & I-A_{N N}
\end{array}\right]^{-1}\left[\begin{array}{c}
\sum_{i}^{N} Y_{1 j} \\
\vdots \\
\sum_{i N j}^{N}
\end{array}\right]=\left[\begin{array}{ccc}
B_{11} & \cdots & B_{1 N} \\
\vdots & \ddots & \vdots \\
B_{N 1} & \cdots & B_{N N}
\end{array}\right]^{-1}\left[\begin{array}{c}
Y_{1} \\
\vdots \\
Y_{N}
\end{array}\right]
$$

Eventually, we can formulate the multiregional input-output model:

$$
\left[\begin{array}{ccc}
X_{11} & \cdots & X_{1 N} \\
\vdots & \ddots & \vdots \\
X_{N 1} & \cdots & X_{N N}
\end{array}\right]=\left[\begin{array}{ccc}
B_{11} & \cdots & B_{1 N} \\
\vdots & \ddots & \vdots \\
B_{N 1} & \cdots & B_{N N}
\end{array}\right]\left[\begin{array}{ccc}
Y_{11} & \cdots & Y_{1 N} \\
\vdots & \ddots & \vdots \\
Y_{N 1} & \cdots & Y_{N N}
\end{array}\right]
$$

In this model we have $\mathrm{N}$ countries and $\mathrm{S}$ sectors, $\mathrm{B}$ means a matrix with SNXSN dimension, $\mathrm{X}$ and $\mathrm{Y}$ mean $\mathrm{SNxN}$ matrices.

B-means the total amount of gross output in producing state $\mathrm{i}$ needed to fulfill final demand in destination state $\mathrm{j}$

$\mathrm{X}$-is gross output decomposition matrix that means gross output produced in state $\mathrm{i}$ and absorbed in state $\mathrm{j}$

$\mathrm{Y}$-is the final demand matrix that means gross output produced in state $\mathrm{i}$ and consumed in state $\mathrm{j}$

Then we create value added production matrix $\hat{V} B Y$

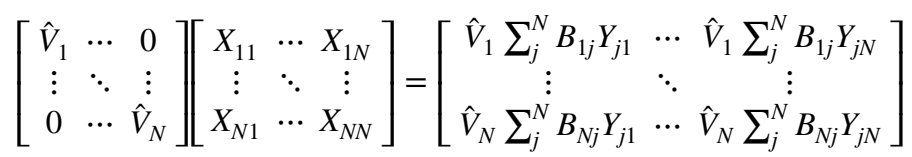


Elements in diagonal matrix mean value added absorbed at home, in turn, all elements off diagonal matrix mean value added absorbed abroad (value added embodied in partner's gross exports)

$$
\text { VAExports }_{\mathrm{i}}=\sum_{j \neq i}^{N} V X_{i j}=V_{i} \sum_{j \neq i}^{N} \sum_{n=1}^{N} B_{i n} Y_{n j}=V_{i} \sum_{j \neq i}^{N} B_{i i} Y_{i j}+V_{i} \sum_{j \neq 1}^{N} B_{i j} Y_{j j}+V_{i} \sum_{j \neq i}^{N} \sum_{t \neq i j}^{N} B_{i j} Y_{j t}
$$

where $V_{i} \sum_{j \neq i}^{N} B_{i i} Y_{i j}$ value added embodied in final goods exports; $V_{i} \sum_{j \neq 1}^{N} B_{i j} Y_{j j}$ value added embodied in gross exports of intermediate products; $V_{i} \sum_{j \neq i}^{N} \sum_{t \neq i j}^{N} B_{i j} Y_{j t}$ so called indirect value added embodied in gross exports.

If we want to present import foreign content embodied in county's gross exports we should formulate it as follows:

$$
\mathrm{VS}=\sum_{j \neq i}^{N} V_{j} B_{j i} E_{i *}=\sum_{t \neq i}^{N} \sum_{j \neq i}^{N} V_{t} B_{t i} Y_{i j}+\sum_{t \neq i}^{N} \sum_{j \neq i}^{N} V_{t} B_{t i} A_{i j}\left(I-A_{j j}\right)^{-1} Y_{j j}+\sum_{j \neq i}^{N} V_{t} B_{t i}\left(I-A_{j j}\right)^{-1} E_{j *}
$$

where $\sum_{t \neq i}^{N} \sum_{j \neq i}^{N} V_{t} B_{t i} Y_{i j}$ foreign value added embodied in final goods exports; $\sum_{t \neq i}^{N} \sum_{j \neq i}^{N} V_{t} B_{t i} A_{i j}\left(I-A_{j j}\right)^{-1} Y_{j j}$ foreign value added embodied in gross exports of intermediate products; $\sum_{j \neq i}^{N} V_{t} B_{t i}\left(I-A_{j j}\right)^{-1} E_{j *}$ so called double-counted value added of intermediate goods produced abroad.

In the final step, we formulate exports of intermediate goods that are used as inputs by foreign countries to produce their gross exports:

$$
\mathrm{VSI}=V_{i} \sum_{j \neq i}^{N} B_{j i} E_{i *}=V_{i} \sum_{t \neq i j}^{N} \sum_{j \neq i}^{N} B_{i j} Y_{j t}+V_{i} \sum_{t \neq i j}^{N} \sum_{j \neq i}^{N} B_{i j} A_{i j} A_{j t} X_{t}+V_{i} \sum_{i \neq i j}^{N} \sum_{j \neq i}^{N} B_{i j} Y_{j i}+V_{i} \sum_{j \neq i}^{N} B_{i j} A_{j i} X_{i}
$$

where $V_{i} \sum_{t \neq i j}^{N} \sum_{j \neq i}^{N} B_{i j} Y_{j t}$ indirect value added embodied in gross exports; $V_{i} \sum_{t \neq i j}^{N} \sum_{j \neq i}^{N} B_{i j} A_{i j} A_{j t} X_{t}$ exports of intermediate goods which will be used abroad to produce gross exports for intermediate products; $V_{i} \sum_{t \neq i j}^{N} \sum_{j \neq i}^{N} B_{i j} Y_{j i}$ domestic value added that return by final production; $V_{i} \sum_{j \neq i}^{N} B_{i j} A_{j i} X_{i}$ domestic value added that return by imports of intermediate goods.

Eventually, the decomposition of gross exports may be formulated:

$$
\begin{aligned}
\mathrm{DCP}= & {\left[\mathrm{V}_{\mathrm{i}} \sum_{j \neq i}^{N} B_{i i} Y_{i j}+V_{i} \sum_{j \neq 1}^{N} B_{i j} Y_{j j}+V_{i} \sum_{j \neq i}^{N} \sum_{t \neq i j}^{N} B_{i j} Y_{j t}\right] } \\
& +\left[\sum_{t \neq i}^{N} \sum_{j \neq i}^{N} V_{t} B_{t i} Y_{i j}+\sum_{t \neq i}^{N} \sum_{j \neq i}^{N} V_{t} B_{t i} A_{i j}\left(I-A_{j j}\right)^{-1} Y_{j j}+\sum_{j \neq i}^{N} V_{t} B_{t i}\left(I-A_{j j}\right)^{-1} E_{j *}\right] \\
& +\left[V_{i} \sum_{t \neq i j}^{N} \sum_{j \neq i}^{N} B_{i j} Y_{j i}+V_{i} \sum_{t \neq i j}^{N} \sum_{j \neq i}^{N} B_{i j} A_{j i}\left(I-A_{i i}\right)^{-1} Y_{i i}+V_{i} \sum_{j \neq i}^{N} B_{i j} A_{j t}\left(I-A_{i i}\right)^{-1} E_{i *}\right]
\end{aligned}
$$


These formulas can be explained:

$$
\mathrm{V}_{\mathrm{i}} \sum_{j \neq i}^{N} B_{i i} Y_{i j}+V_{i} \sum_{j \neq 1}^{N} B_{i j} Y_{j j}+V_{i} \sum_{j \neq i}^{N} \sum_{t \neq i j}^{N} B_{i j} Y_{j t} \text { and } V_{i} \sum_{t \neq i j}^{N} \sum_{j \neq i}^{N} B_{i j} Y_{j i}+V_{i} \sum_{t \neq i j}^{N} \sum_{j \neq i}^{N}
$$
$B_{i j} A_{j i}\left(I-A_{i i}\right)^{-1} Y_{i i}+V_{i} \sum_{j \neq i}^{N} B_{i j} A_{j t}\left(I-A_{i i}\right)^{-1} E_{i *}$ create domestic value added embodied in partner's gross exports (IV), and $\sum_{t \neq i}^{N} \sum_{j \neq i}^{N} V_{t} B_{t i} Y_{i j}+\sum_{t \neq i}^{N} \sum_{j \neq i}^{N} V_{t} B_{t i} A_{i j}\left(I-A_{j j}\right)^{-1} Y_{j j}$ $+\sum_{j \neq i}^{N} V_{t} B_{t i}\left(I-A_{j j}\right)^{-1} E_{j *}$ means foreign value added embodied in county's gross exports $(\mathrm{FV})$.

When we apply this methodology, we are able to construct an index that makes us assess the position of the country (upstream or downstream market in the GVC in any given industry). We are able also formulate a separate index that assesses to what extent a country-industry is involved in the global production linkages.

Using this index, it is possible to evaluate to what extend home-country's exports of intermediate goods in given industry are used by other states, with that state's use of imported intermediate goods in the same industry. If a country is located in upstream market in global production linkages, it means that the country produces inputs (value added) for its trade partners, by providing raw materials or manufactured intermediates. For such a state, indirect domestic value added share in gross exports will be larger than foreign value added embodied in gross exports share. If a country is located in downstream market in global production linkages, it means that the country uses a large portion of other countries' intermediate goods to produce final goods for gross export. In this case its foreign value added share will be larger than domestic value added share.

We formulate a 'state-industry' index for the GVCs position as the log ratio of a country-sector's supply of intermediate goods used in other countries' exports to the use of imported intermediate goods in their own production.

$$
\text { GVC_POSITION }_{\mathrm{ir}}=\operatorname{Ln}\left(1+\frac{I V}{E}\right)-\operatorname{Ln}\left(1+\frac{F V}{E}\right)
$$

If the state-industry locates in upstream in a supply chain, the numerator tends to be large. If the state-industry locates in downstream market, then the denominator tends to be large.

Of course, both states may have the same GVC position index in one industry/sector while having very different levels of participation in GVCs. Therefore, the position index must be applied in combination with another index that presents the significance of the global supply chain for that state-sector. So, we formulate a GVC participation index as

$$
\text { GVC_PARTICIPATION }=\frac{I V}{E}+\frac{F V}{E}
$$

When a state is placed in the upstream segment in a production linkages, it is probably that this country is characterized by the high level of forward participation relative to backward participation. This means that the analysed states depends more on its own production (value added). If a state specializes in the last stages of production, which mean downstream segment of production, it is probably that this country imports a lot of intermediate goods from another countries and therefore it is characterized by the high level of backward participation. In or formula the GVC relative position index is constructed in such a way that states with high forward relative to backward participation have a value above zero. 
Data referring to trade in value-added statistics are collected by the OECD/WTO Trade in Value Added Database. We collected the data and constructed: (1) an index that helps us to assess if a country is likely to be upstream or downstream of the global value chain (GVC) in terms of a given sector, and (2) an index that helps us to assess the extent to which a country is involved in the global production chain in terms of a given sector.

\section{Sectoral connections}

In this section we tried to investigate the connections between China and the V4 states in terms of selected sectors. First, we try to identify the positions of the V4 countries and China depending on each industry generally. We compared 2009 and 2014 to indicate any improvements/deteriorations in the V4 states positions in GVCs. Then we study each of selected sectors in terms of production linkages between the V4 states and China, apart from the other countries presented in Table 2. We decided to examine five sectors where connections between China and the V4 states is most visible in terms of foreign value added and domestic value added embodied in gross exports: manufacture of motor vehicles, trailers and semi-trailers; manufacture of computer, electronic and optical products; mining and quarrying; basic metals and fabricated metal products; and manufacture of electrical equipment (Table 1).

In Table 1 we observed a high level of foreign value added embodied in gross exports of the V4 states in almost all analysed sectors, except for mining and quarrying. The dependence on foreign value added was also reflected in relative low domestic value added of the V4 states embodied in gross exports of their trade partners in 2014. It means that the analysed sectors in all V4 states were strongly connected to foreign production networks, especially in manufacture of motor vehicles, trailers and semi-trailers, manufacture of computer, electronic and optical products, and manufacture of electrical equipment. Unfortunately, these connections are more backward than forward in some cases. It means, that these countires specialize in the last stages of production and import a lot of intermediate goods from another countries. The largest share of domestic value added embodied in partner's gross exports we observed in all analysed sectors in Poland. In case of China, we observed the opposite situation-this country relied on its own value added more than on the value added from its trade partners in all analysed sectors. The largest China's dependence on foreign value added was observed in manufacture of computer, electronic and optical products $(32.26 \%)$. In turn, manufacture of electrical equipment was characterized by the largest level of domestic value added embodied in gross exports of Chinese trade partners (56.02\%) (Table 1).

Manufacture of motor vehicles, trailers and semi-trailers is the domain of the V4 states and has a long tradition. It was visible in 2009, when these states were among the world leaders in this industry. Till 2014, these countries were still in the lead of the car production network, but their GVC positions were much lower than 5 years earlier. This might be explained by stronger position of German automotive industry, Chinese appearance in this sector and increasing labor costs in the V4 states (the labor productivity in the V4 countries has increased most dynamically in car industry). Recently, this sector has become the driving force behind exports and has attracted considerable FDI to this region. Eventually, over the past three decades, the V4 states have built major automotive industry clusters with the well-knowing brands and complex supplier network. The process of production and assembly concentration was supported by well-developed transport infrastructure and efficient logistic networks. Assembly and production plants in the V4 countries have clustered in 


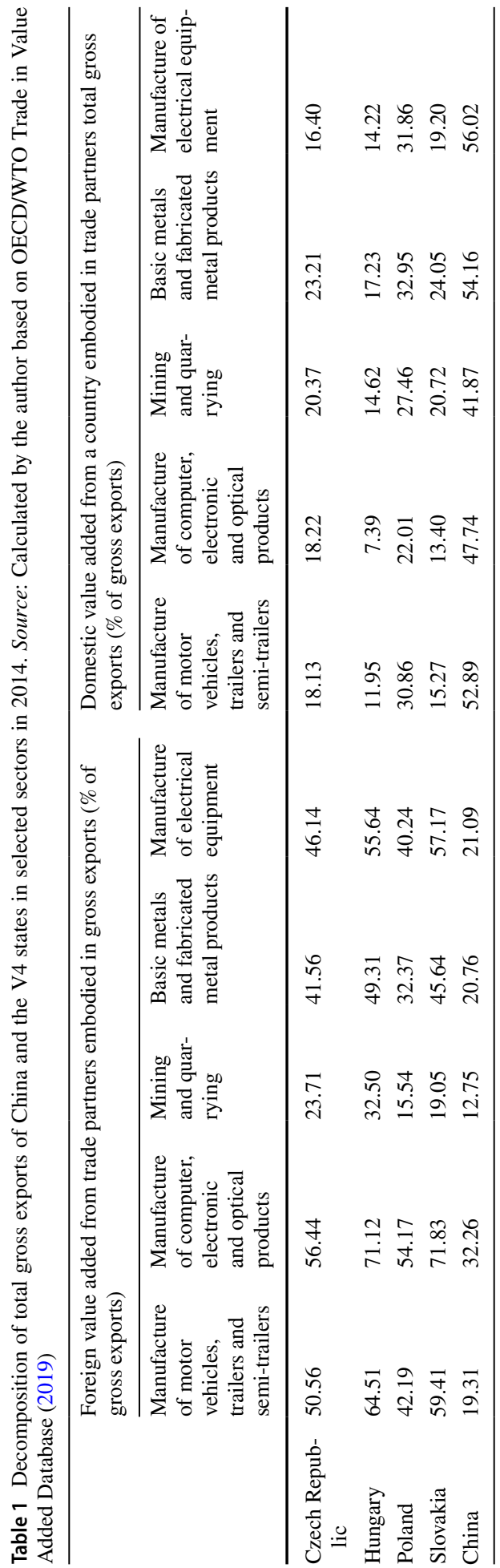




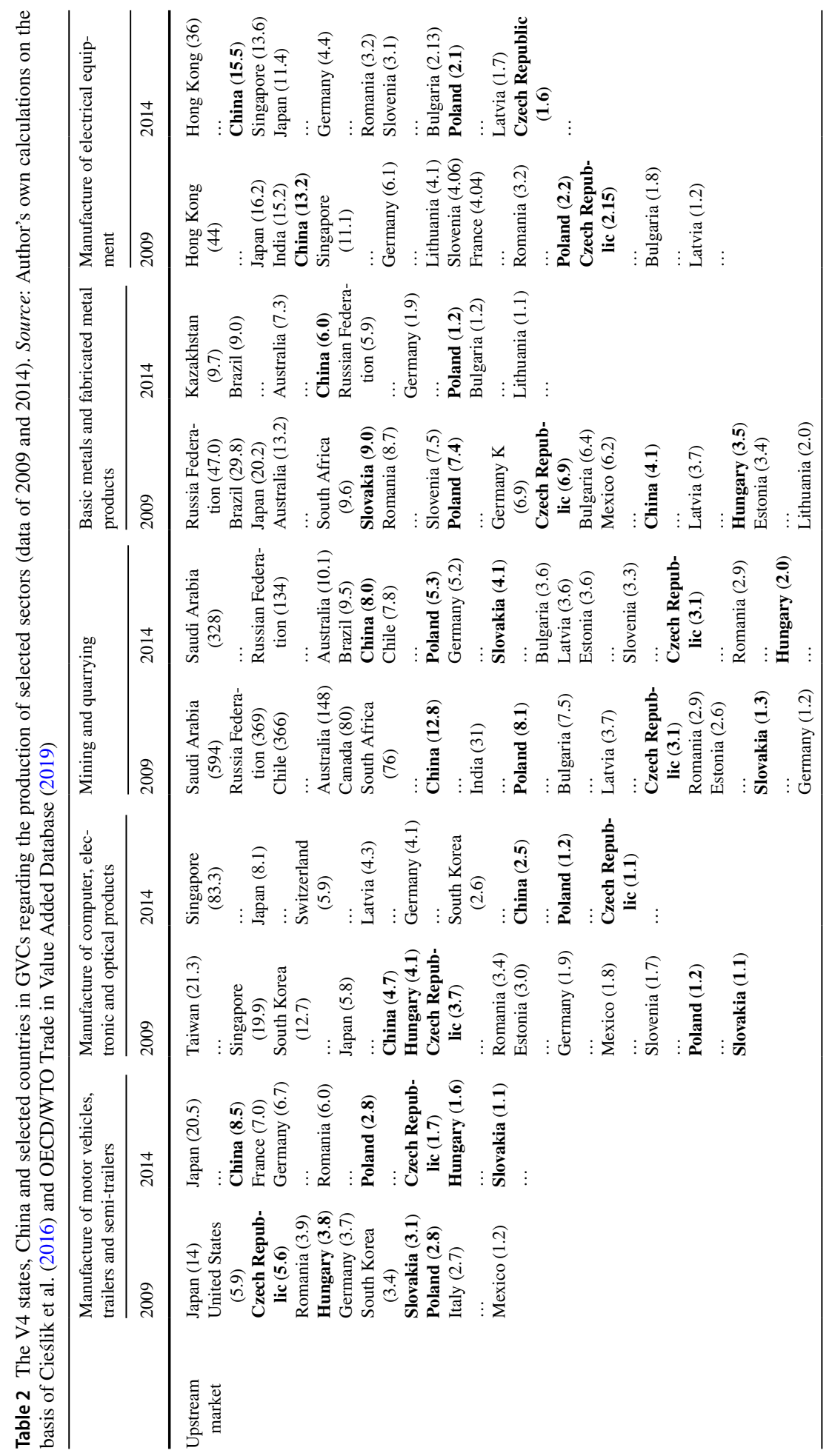




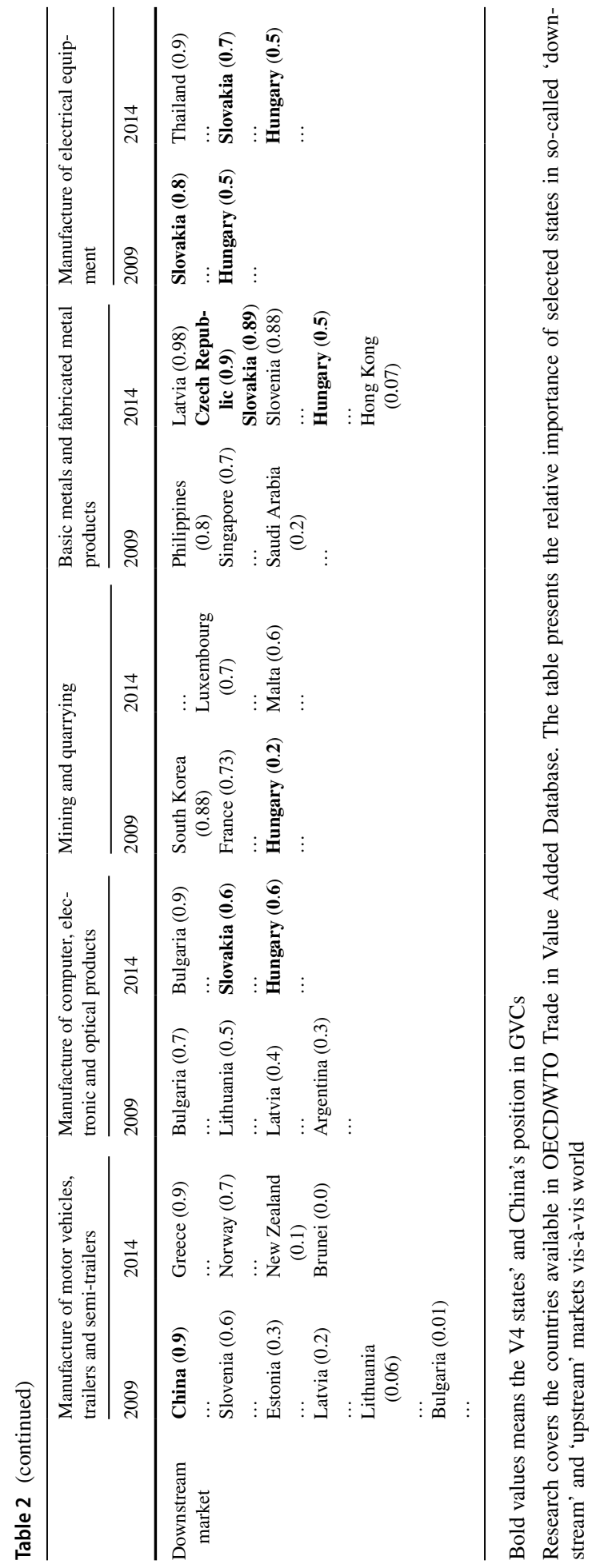


a relatively small area, covering Eastern and Central Czech Republic, Northern Hungary, Southern Poland and West Slovakia.

In turn, China does not have such a long tradition in car industry, but it is characterized by the high production growth. In 2009 China belonged to the downstream market in this branch, but till 2014 it has improved position to the upstream market. In 2009 China was much lower in GVCs relative position than all V4 states, but within 5 years the country became a world leader in this sector (Table 2). The car sector in China is dominated by foreign vehicle manufacturers. Among the most popular car producers in 2014 we should mention inter alia: Shanghai General Motors Company Ltd., Shanghai Volkswagen Automotive Co. Ltd., FAW-VW Automobile Co. Ltd., Dongfeng Nissan Passenger Vehicle Co. Ltd., Beijing Hyundai Motor Company, Chang' an Ford Automobile Co., or FAW Toyota Motor Sales Co. Ltd.

Manufacture of computer, electronic and optical products, in turn, has traditionally been the domain of East Asian well-developed countries and Western Europe. In 2009 and 2014, these countries were the leaders in analysed industry. Recently, China has grown as a new player in this sector, but its positions in GVCs deteriorated between 2009 and 2014, perhaps due to a higher dependence on the intermediate parts from developed countries. Nevertheless, China overtook the V4 countries. We suppose that many years will pass before the V4 states' economy achieves a comparable level of technological advancement to the leaders in this sector. When we compare the V4 states' positions in GVCs between 2009 and 2014, we do not see any considerable improvements. Poland and the Czech Republic held the highest positions in this industry in 2014, but they were far behind China. The worst GVC positions occupied Slovakia and Hungary. Moreover, these two states deteriorated their positions significantly - they moved from the upstream to the downstream market (Table 2).

In terms of mining and quarrying, all analyzed states can be found in the upstream market, though this sector is not predominant neither in the V4 states nor China. Obviously, analysed countries are situated in GVCs far behind the mining-giants as Saudi Arabia or the Russian Federation. Nevertheless, almost all V4 states (except for Hungary) were in the upstream market in analysed years. The interesting case was Hungary in 2009, where the mining sector's share in GDP was relative high, but this production located the country in the downstream market. This can be explained by the relative high share of foreign value added embodied in Hungary's gross exports, which was one of the least expanded among V4 states. Till 2014, Hungary improved its position. Between 2009 and 2014 China also deteriorated its position in GVC in this industry, but surpassed all V4 states significantly (Table 2). This can be explained by the large area which is rich in natural resources.

Basic metals and fabricated metal products manufacturing has the long traditions in the V4 states and China which have derived from resource-rich areas. In the V4 states and China exist the special clusters of this industry. This branch is directly dependent on the condition of car in analysed countries. Nevertheless, we observed significant deterioration in the GVC positions of the V4 states. In 2009, all V4 states located in the upstream market, but in 2014 only Poland stayed in this segment. We may notice the most dramatic decrease in GVC position in Slovakia (Table 2). This deterioration might be explained by decreasing of FDI inflows due to introduction of some unfavourable changes in tax system, labor law etc.

In terms of manufacture of electrical equipment industry we cannot observe any considerable changes in positions of analysed countries in GVCs. China surpassed the V4 states and placed very high in the upstream market. It is worth to add that the first place of Hong Kong derived from the fact, that Hong Kong has played an extremely important role to Chinese exporters, especially exporters from Guangdong province. They have shifted their export flows through this special administrative region since China's government slowly opened the economy. Only Poland and the Czech Republic were located in the upstream 
market of electrical equipment industry both in 2009 and 2014, whereas Slovakia and Hungary did not manage to improve their positions from 2009 (Table 2).

According to our research, manufacture of computer, electronic and optical products and manufacture of electrical equipment are the most connected sectors in the V4 states to Chinese value added (Table 4). It is not surprising that we could see the largest influence of Chinese value added in these two sectors, because they have attracted the largest share of Chinese FDI recently. The electronic industries dominated the Chinese FDI in the V4 countries. In Hungary we have observed investments of Wanhua, Huawei, ZTE, Lenovo, Sevenstar Electronics, BYD Electronics and Comlink. In turn, LiuGong Machinery, Haoneng Packaging, Shanxi Yuncheng Platemaking Group and Sino Frontier Properties Ltd have invested in Poland. The Czech Republic has attracted Chinese Shanxi Yuncheng, Changhong, Noark, Huawei, ZTE and Shanghai Maling. In Slovakia SaarGummi, ZVL Auto, Inalfa Roof Systems, Mesnac, Lenovo and Huawei have invested so far.

In analysed period, China has surpassed Germany, South Korea, and Japan gradually, and has become a leader among value added providers in the V4 states in manufacture of computer, electronic and optical products. In 2014, except for Hungary, China was the leading supplier of value added in this sector's gross exports. In case of Hungary, only Germany surpassed China in this sector. When we took into consideration the manufacture of electrical equipment industry in 2014, China was located on the 2nd position in all V4 states. Germany had a predominant role in value added supply in all V4 countries (Table 3 ).

Among all V4 states, Slovakia characterizes the strongest dependence on Chinese value added in manufacture of computer, electronic and optical products and manufacture of electrical equipment (17.3\% of manufacture of computer, electronic and optical products' gross exports derived from China; $5.7 \%$ of manufacture of electrical equipment gross exports stem from China). Moreover, this connections are growing stronger: in 2005 these shares amounted to $5.4 \%$ and $2.4 \%$ respectively. Similar increasing tendency can be observed in Poland. Between 2005 and 2014, Chinese value added embodied in Polish manufacture of computer, electronic and optical products' gross exports increased from only $4.0 \%$ to $14.6 \%$. Chinese value added embodied in Polish manufacture of electrical equipment also increased from $1.4 \%$ in 2005 to $5.0 \%$ in 2014 . The Czech Republic and Hungary were less connected to Chinese value added in their gross exports in analysed sectors. The Czech Republic's gross exports of manufacture of computer, electronic and optical products' relied on China's value added in $13.9 \%$ in 2014 (increased from $6.4 \%$ in 2005). In 2014, Hungarian gross exports of this industry were dependent on China in $12.7 \%$ (increased from $8.2 \%$ in 2005). In terms of gross exports of manufacture of electrical equipment both countries' gross exports relied less on Chinese value added in 2014: in 3.8\% and 3.6\% respectively (Table 4).

Gross exports of the V4 states were less connected to Chinese value added in car industry. Although we observed increasing of value added from China in this sector, but the levels were still low when we compared Chinese engagement into sector manufacture of computer, electronic and optical products. The largest share of value added from China in gross exports of manufacture of motor vehicles, trailers and semi-trailers was observed in the Czech Republic (3.3\% in 2014), where China was ranked on the 3rd position among all value added providers (after Germany and Poland). Other V4 states' share amounted to $3.1 \%$. It proves that this sector of V4 states is more tied to the European Union's value chains, especially to German and Italian, than to Chinese value chains. Moreover, there are a lot of fluctuations in Chinese value added embodied in the V4 states' gross exports in this industry. For example, in 2009, 3.4\% of Hungarian gross exports of manufacture of motor 

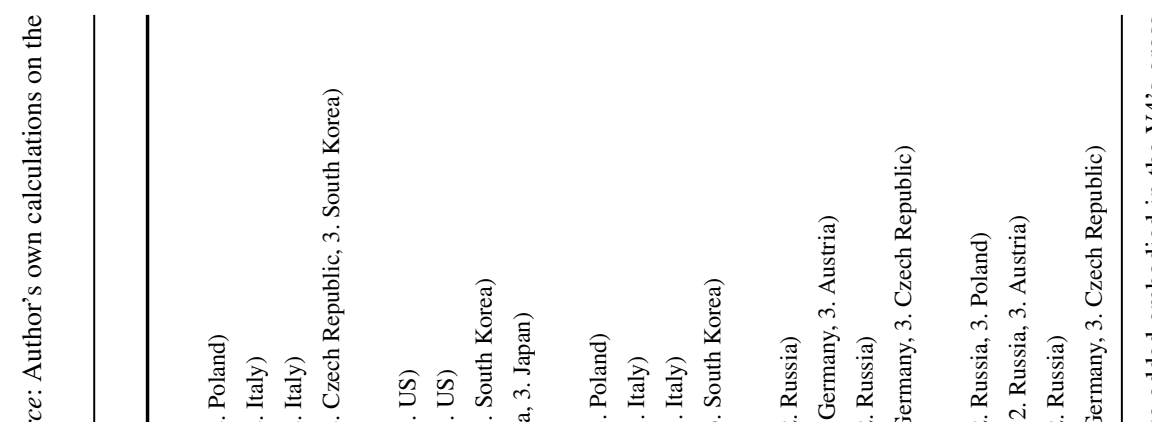

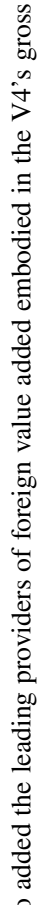
त त 4 i लं $\dot{m}$ के

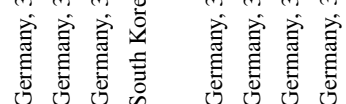

宓

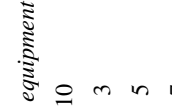

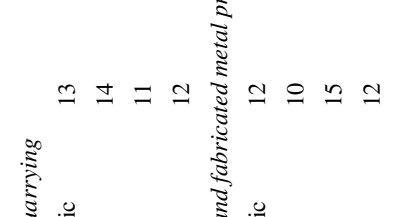




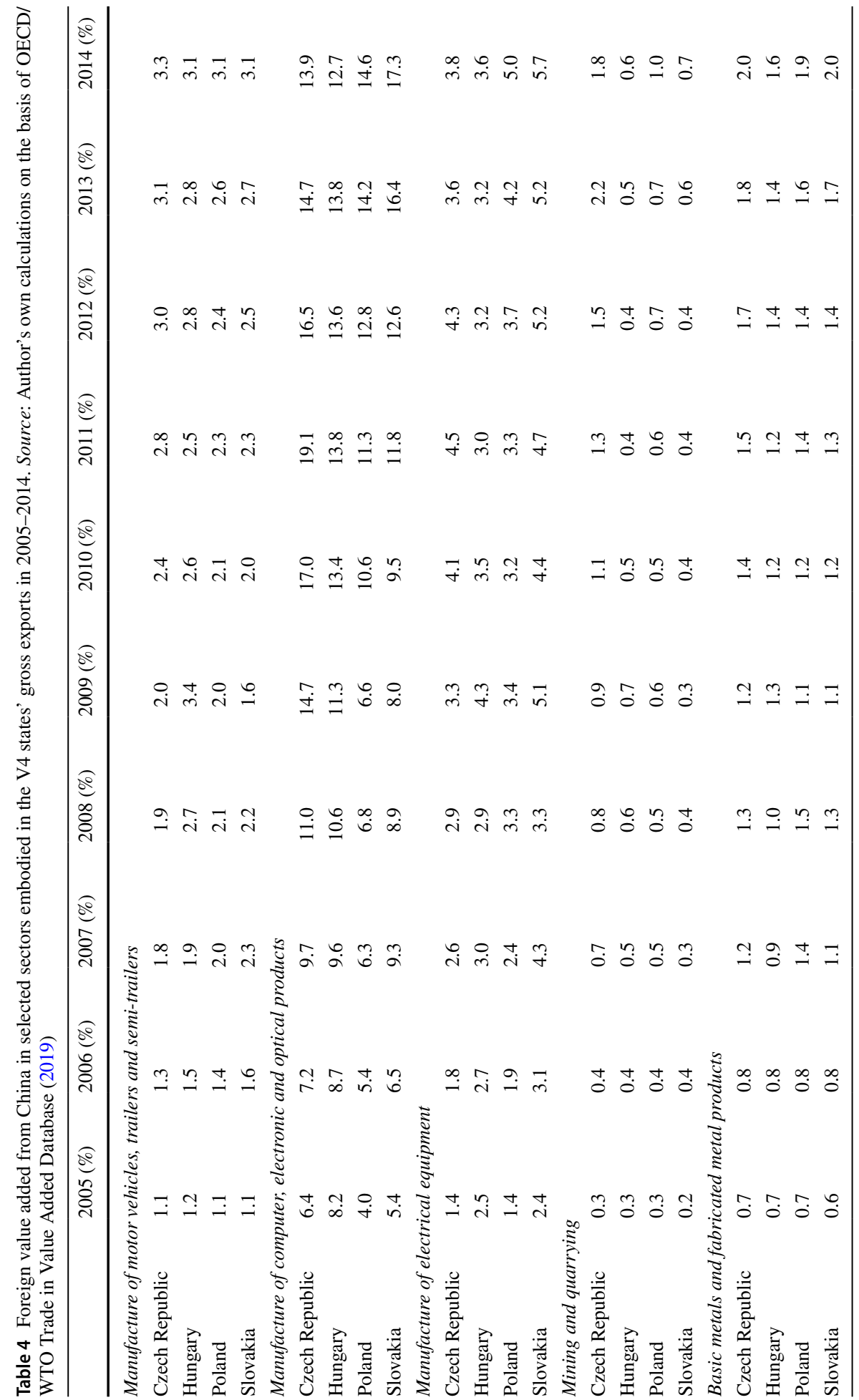


vehicles, trailers and semi-trailers relied on Chinese value added (China was ranked high among value added suppliers-the 3rd position), but a year later it diminished to $2.6 \%$ and to the 6th position. Generally, when we compare 2005 and 2014, we can observe substantial growth in Chinese value added embodied in the V4 states car industry from around 1\% to more than $3 \%$ (Tables 3, 4).

Basic metals and fabricated metal products and mining and quarrying were the most independent of Chinese value added among analysed sectors. Though we observe a slight growth in Chinese value added embodied in those industries, especially in the Czech Republic and Poland. In the Czech Republic, China improved its position in value added embodied in gross exports of basic metals and fabricated metal products industry from 12th in 2005 to 4th in 2014. In Poland, the growth was more significant - from 15th to 3rd position. The same tendency we observed in mining and quarring. Hungary was the least dependent on Chinese value added in these sectors (Tables 3, 4). Russia and Germany were the leaders in these industries.

It is worth to add that in terms of almost all analysed sectors (and general engagement in Central and Eastern Europe), China has improved its position steadily. This may be explained by the rising interest of China in Central and Eastern Europe in the 11th 5 Years Plan (2006-2011). At that time Chinese investors start to realize the investment potential of this European region. Moreover, the cooperation opportunities were further strengthened by serious economic problems in the Eurozone and China began to treat the V4 states as "window of opportunity" (Liu 2013, 2014).

When we analyse the role of the V4 member states in Chinese gross exports, we do not observe a great interdependence. Moreover, we can notice fluctuations in the V4 states' value added embodied in Chinses gross exports in analysed sectors between 2005 and 2014 (Table 6). It means that the V4 states might be treated as an insignificant and 'ad hoc' partner for China and could be replaced anytime. Furthermore, it implies that the V4 states' role in the Chinese GVCs is not as strong as their role in the EU's GVCs and that they presumably operate in the lower market segments generally (Cieślik et al. 2016).

When we analyse domestic value added of the V4 states embodied in Chinese gross exports, we see the highest share in manufacture of motor vehicles, trailers and semi-trailer sector. Nevertheless, these shares were insignificant, when we compare them to the shares of Chinese value added embodied in the V4 states' gross exports. Poland and Slovakia generally occupied the highest positions as value added providers to Chinese manufacture of car industry gross exports in 2005-2014. Only in 2006-2009, Hungary played a predominant role. It is not surprising, that all V4 states were ranked most favourable in manufacture of motor vehicles, trailers and semi-trailer sector. They have specialised in this industry, but, their roles in Chinese gross exports were still low. In 2014, the most important suppliers of domestic value added embodied in Chinese gross exports in car industry were: Japan, the United States and Germany (Tables 5, 6).

In the rest of analysed sectors, the V4 states' value added was insignificant for Chinese gross exports. The shares of V4 countries' value added in Chinese gross exports were as low as their positions among Chinese trade partners in terms of value added. For example, in 2005-2014, Poland was located the highest in Chinese manufacture of computer, electronic and optical products' gross exports, but still far behind the most important value added suppliers, which were South Korea, Taiwan and Japan. In 2014, we observed similar situation in terms of manufacture of electrical equipment, where Poland seemed to be again the most important provider of domestic value added. But Japan, the United States and South Korea were the leading exporters of their value added to China in analysed sector. An identical situation was observed in mining and quarrying: this sector was 
Table 5 The V4 states positions in selected sectors in terms of domestic value added embodied in the Chinese gross exports in 2005-2014. Source: Author's own calculations on the basis of OECD/WTO Trade in Value Added Database (2019)

\begin{tabular}{|c|c|c|c|c|c|c|c|c|c|c|}
\hline & 2005 & 2006 & 2007 & 2008 & 2009 & 2010 & 2011 & 2012 & 2013 & 2014 \\
\hline \multicolumn{11}{|c|}{ Manufacture of motor vehicles, trailers and semi-trailers } \\
\hline Czech Republic & 43 & 41 & 42 & 41 & 41 & 42 & 38 & 38 & 37 & 38 \\
\hline Hungary & 42 & 35 & 33 & 35 & 37 & 39 & 40 & 40 & 39 & 39 \\
\hline Poland & 38 & 37 & 35 & 36 & 38 & 35 & 36 & 36 & 36 & 33 \\
\hline Slovakia & 46 & 43 & 37 & 39 & 40 & 36 & 34 & 32 & 34 & 34 \\
\hline \multicolumn{11}{|c|}{ Manufacture of computer, electronic and optical products } \\
\hline Czech Republic & 44 & 42 & 40 & 40 & 40 & 40 & 40 & 40 & 40 & 41 \\
\hline Hungary & 42 & 43 & 41 & 43 & 42 & 43 & 42 & 44 & 42 & 42 \\
\hline Poland & 39 & 39 & 39 & 38 & 38 & 39 & 39 & 39 & 39 & 38 \\
\hline Slovakia & 52 & 52 & 51 & 51 & 51 & 52 & 51 & 50 & 48 & 48 \\
\hline \multicolumn{11}{|c|}{ Manufacture of electrical equipment } \\
\hline Czech Republic & 44 & 44 & 45 & 42 & 43 & 42 & 42 & 43 & 43 & 41 \\
\hline Hungary & 45 & 45 & 45 & 45 & 45 & 45 & 45 & 46 & 44 & 44 \\
\hline Poland & 38 & 39 & 35 & 36 & 37 & 38 & 38 & 38 & 37 & 36 \\
\hline Slovakia & 50 & 51 & 51 & 51 & 50 & 51 & 51 & 51 & 49 & 48 \\
\hline \multicolumn{11}{|c|}{ Mining and quarrying } \\
\hline Czech Republic & 44 & 45 & 45 & 44 & 45 & 45 & 44 & 43 & 43 & 43 \\
\hline Hungary & 46 & 46 & 46 & 46 & 46 & 47 & 47 & 47 & 47 & 46 \\
\hline Poland & 41 & 41 & 40 & 40 & 41 & 42 & 41 & 41 & 41 & 39 \\
\hline Slovakia & 51 & 51 & 51 & 51 & 51 & 50 & 49 & 50 & 50 & 50 \\
\hline \multicolumn{11}{|c|}{ Basic metals and fabricated metal products } \\
\hline Czech Republic & 44 & 45 & 44 & 44 & 44 & 45 & 44 & 44 & 44 & 45 \\
\hline Hungary & 51 & 47 & 48 & 49 & 48 & 50 & 50 & 50 & 49 & 48 \\
\hline Poland & 39 & 38 & 38 & 39 & 39 & 40 & 40 & 39 & 36 & 35 \\
\hline Slovakia & 49 & 50 & 52 & 51 & 51 & 52 & 52 & 52 & 52 & 52 \\
\hline
\end{tabular}

We took into consideration 64 countries which were available in a database

dominated by value added from Australia, the United States and Saudi Arabia. The V4 states were insignificant providers of value added in this sector in analysed period. The highest position occupied Poland, but it was still very low (Tables 5, 6).

Similarly to mining and quarrying, in sector basic metals and fabricated metal products none of the V4 states played an important role in Chinese gross exports in 2005-2014. During analysed period, again Poland occupied the highest positions, but still far behind the leading China's value added suppliers in this sector. In 2014, Australia, the United States and Japan ranked on the top positions (Tables 5, 6).

\section{Conclusions}

The paper presented not only the growing China's influence on production linkages with the most internationalised sectors in the V4 states' economies, but also reflected the tendency of the world production fragmentation process. Since the introduction of the OBOR 


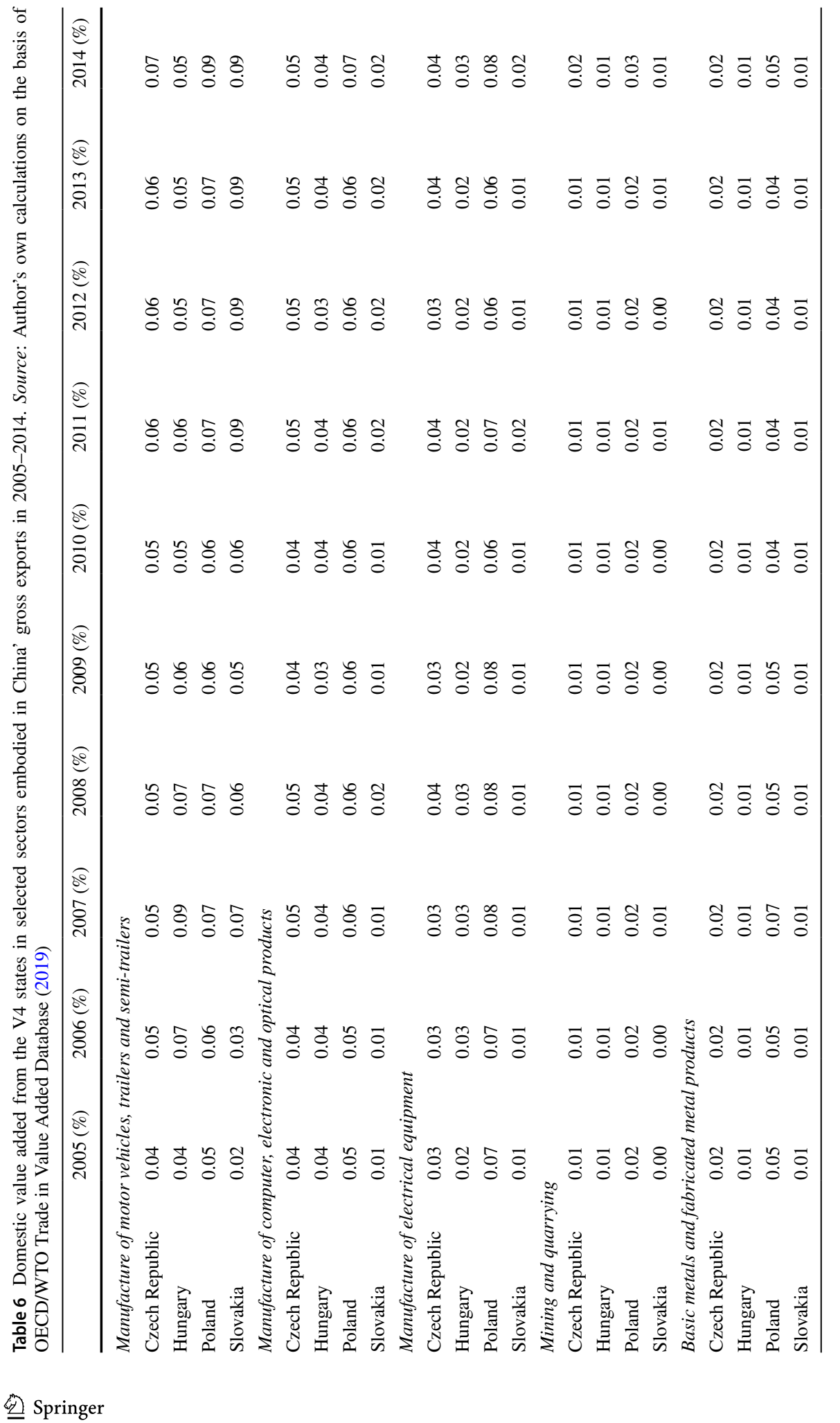


strategy and formula ' $16+1$ ', China has increased its interests in the EU market by growing exports and FDI. The V4 countries have become perfect gateway for Chinese expansion to the EU markets.

Based on our research results, there are no grounds to reject two hypotheses stated at the beginning of this article.

The V4 states have deteriorated their positions in GVCs in relation to China in five analysed sectors significantly. This tendency has been visible since 2006 especially. According to results in Tables 1 and 2, the V4 states were characterized by the high levels of foreign value added embodied in their gross exports of selected sectors. These indicators were much higher than foreign value added embodied in Chinese gross exports. Moreover, even in manufacture of motor vehicles, trailers and semi-trailers, the V4 states could not keep their high positions in GVCs. Eventually, the V4 states have not shown a tendency to improvements in their places in GVCs in analysed sectors.

The study also confirmed hypothesis, that the V4 states have become more dependent on Chinese value added in all analysed sectors, especially in: manufacture of computer, electronic and optical products and manufacture of electrical equipment. Unfortunately, we did not observe an opposite tendency: China' gross exports have been almost independent of the V4 states' value added. According to Table 3, China was the most important or was among the leaders that provided foreign value added to the V4 states. Unfortunately, the V4 states were not so significant for Chinese gross exports, what reflected in their very low positions among value added suppliers in analysed sectors (Tables 3-6). In the key sector for the V4 states-car industry, we also observed grater dependence. Though German value added still dominates in production linkages of this sector, we also noticed increasing influence of Chinese value added. ${ }^{1}$ Even in less connected to Chinese value added sectors (e.g. mining and quarrying; basic metals and fabricated metal products) the dependence has been more visible recently. When we bring together our research results, we can find an increasing sectoral gap between the flows of Chinese and the V4 states' value added embodied in each other gross exports. The V4 coutries' dependence on Chinese value added is growing, while China has not been connected to the V4 states' value added heavily. This implies that the China-V4 value added flows have been more unbalanced and there has not been a noticeable improvement in the role of the V4 states in China's gross exports in analysed sectors.

Of course we should be aware of some limitations of our study. First, we were limited by availability of statistical data. It is possible that the future research into the role of the V4 states in GVCs in particular sectors might be different. It might be also possible that the new, upgrading data will rank the analysed states differently in GVCs in terms of analysed sectors. Nevertheless, observing Chinese trade intensification, these improvements in the V4 states' GVC positions are unlikely. Second, the overall picture of the GVCs participation of the V4 states and China should be extended by analysing of services. Recently, we have observed an increasing role of services, both in international trade due to their tradability and in production networks.

Acknowledgements The article is the result of the research project "Chinese New Silk Road strategy: implications for production linkages between China and Central and Eastern Europe" financed by the National Science Centre, Poland (UMO-2016/23/D/HS4/02748).

\footnotetext{
${ }^{1}$ China has been upgrading its automotive sector by the domestic technological innovation capability and international linkages (Lu et al. 2015).
} 


\section{Compliance with ethical standards}

Conflict of interest On behalf of all authors, the corresponding author states that there is no conflict of interest.

Open Access This article is distributed under the terms of the Creative Commons Attribution 4.0 International License (http://creativecommons.org/licenses/by/4.0/), which permits unrestricted use, distribution, and reproduction in any medium, provided you give appropriate credit to the original author(s) and the source, provide a link to the Creative Commons license, and indicate if changes were made.

\section{References}

Akbar, Y., Ferencikova, S.: Industrial clustering and global value chains in central and Eastern Europe: role of multinational enterprises in industrial upgrading. Prague Econ. Pap. 16(3), 237-251 (2007)

Altomonte, C., di Mauro, F., Ottaviano, G., Rungi, A., Vicard, V.: Global value chains during the great trade collapse: A bullwhip effect? Working Paper Series, 1412, European Central Bank (2012)

Amador, J., Cappariello, R., Stehrer, R.: Global value chains: A view from the Euro Area. CompNetConference, Washington, D.C., pp. 16-17 (2013)

Ando, M., Kimura, F.: Production linkage of Asia and Europe via central and Eastern Europe. J. Econ. Integr. 28(2), 204-240 (2013)

Arghyrou, M.G.: EU participation and the external trade of Greece: an appraisal of the evidence. Appl. Econ. 32(2), 151-159 (2000)

Augier, P., Gasiorek, M., Lai, Tong C.: The impact of rules of origin on trade flows. Econ. Policy 20(43), 567-624 (2005)

Bair, J.: Analysing global economic organization: embedded networks and global chains compared. Econ. Soc. 37(3), 339-364 (2008)

Baldone, S., Sdogati, F., Tajoli, L.: Patterns and determinants of international fragmentation of production: evidence from outward processing trade between the EU and Central Eastern European countries. Rev. World Econ. 137, 80-104 (2001)

Baldone, S., Sdogati, F., Tajoli, L.: On some effects of international fragmentation of production on comparative advantages, trade flows and the income of countries. World Econ. 30, 1726-1769 (2007)

Behar, A., Freund, C.: Factory Europe? Brainier but not Brawnier. FREIT Working Paper 312, Forum for Research in Empirical International Trade (FREIT) (2011)

Bjelić, P., Dragutinović Mitrović, R., Popović Petrović, I.: Administrative barriers to trade as predominant non-tariff barriers. In: The 3rd International Conference on International Trade and Investment, 4-6 September, University of Mauritius and WTO, Mauritius (2013)

Brada, J.C.: The political economy of communist foreign trade institutions and policies. J. Comp. Econ. 15, 211-238 (1991)

Buckley, P.J.: Time to learn? assignment duration in global value chain organization. J. Bus. Res. (2018). https://doi.org/10.1016/j.jbusres.2018.01.011

Chen, X.: Trade and economic cooperation between China and CEE countries. Working Paper Series on European Studies, Institute of European Studies, Chinese Academy of Social Sciences (2012)

Cieślik, E.: Prospects for trade growth between Poland and China. Stud. Ekon. Polska Akad. Nauk. 4, 495515 (2014)

Cieślik, E.: the new silk road: seeking opportunities for polish exports in the Chinese market. Zesz. Naukowe Szk. Gł. Gospod. Wiej. Warsz. 17(32), 4 (2017)

Cieślik, E., Biegańska, J., Środa-Murawska, S.: The intensification of foreign trade in post-socialist countries and their role in global value chains. Acta Oecon. 66(3), 465-487 (2016)

Crang, M., Hughes, A., Gregson, N., Norris, L., Ahamed, F.: Rethinking governance and value in commodity chains through global recycling networks. Trans. Inst. Br. Geogr. 38(1), 12-24 (2013)

Damijan, J., Crt, K., Rojec, M.: Global supply chains at work in central and Eastern European countries: impact of FDI on export restructuring and productivity growth. Institute for Economic Research (2013)

De Simone, G.: Trade in parts and components and the Industrial Geography of Central and Eastern European Countries. Rev World Econ 144(3), 428-457 (2008)

Deng, J., Liu, X.: Deepening the " $16+1$ cooperation" relationship to foster the new growth pole of Sino-EU Trade. In: 16+1 Cooperation and China-EU Relationship. China-CEE Institute, pp. 4-23 (2018) 
Dobrinsky, R.: Economic transformation and the changing patterns of European east-west trade. In: Dobrinsky, R., Landesmann, M. (eds.) Transforming Economies and European Integration, pp. 86-115. Edward Elgar, Aldershot (1995)

Egger, H., Egger, P.: The determinants of EU processing trade. World Econ. 28, 147-168 (2005)

Éltető, A., Szunomár, Á.: Ties of Visegrád countries with East Asia-trade and investment. Institute of World Economics, Centre for Economic and Regional Studies, Hungarian Academy of Sciences, Budapest, p. 29 (IWE Working Papers; 214) (2015)

Éltetô, A., Toporowski, P.: Effects of the international crisis-development of four Central European countries' trade with Asia. Paper Presented at the 15th ETSG conference, Birmingham, 12-14 September (2013). http://www.etsg.org/ETSG2013/Papers/297.pdf

Fortwengel, J.: Upgrading through Integration? the case of the central Eastern European automotive industry. Transci. J. 2(1), 1-25 (2011)

Foster, N., Stehrer, R., Timmer, M.: International fragmentation of production, trade and growth. Impacts and prospects for EU member states. European Economy Economic papers 484, European Commission, DG ECFIN

Frank, K.: Development of Slovak foreign trade with Asia. Institute for Economic Research of the Slovak Academy of Sciences

Fung, K.C., Korhonen, I., Li, K., Ng, F.: China and Central and Eastern European countries: Regional networks, global supply chain or international competitors? J. Econ. Integr. 24(3), 476-504 (2009)

Gereffi, G.: Global value chains in a post-Washington consensus world. Rev. Int. Polit. Econ. 21(1), 9-37 (2014)

Gereffi, G., Fernandez-Stark, K.: Global value chain analysis: a primer. The Duke Center on Globalization, Governance and Competitiveness

Gereffi, G., Humphrey, J., Sturgeon, T.: The governance of global value chains. Rev. Int. Polit. Econ. 12(1), 78-104 (2005)

Helg, R., Tajoli, L.: Patterns of international fragmentation of production and the relative demand for labor. N. Am. J. Econ. Finance 16, 233-254 (2005)

Hummels, D., Ishii, J., Yi, K.: The nature and growth of vertical specialization in world trade. J. Int. Econ. 54, 75-96 (2001)

IBRD and WTO: Measuring and analyzing the impact of GVCs on economic development. Global Value Chain Development Report (2017)

Jacoby, W.: Managing globalization by managing central and Eastern Europe: the EU's Backyard as threat and opportunity. J. Eur. Public Policy 17(3), 416-432 (2010)

Johnson, R.C., Noguera, G.: Proximity and production fragmentation. Am. Econ. Rev. 102(3), 407-411 (2012)

Jürgens, U., Krzywdzinski, M.: Changing east-west division of labour in the European automotive industry. Eur. Urban Reg. Stud. 16(1), 27-42 (2009)

Kaminski, B., Ng, F.: Trade and production fragmentation: central European economies in European union networks of production and marketing. World Bank Policy Research Working Paper, 2611 (2001)

Kaminski, B., Ng, F.: Production Disintegration and Integration of Central Europe into Global Markets. Int. Rev. Econ. Financ. 14, 377-390 (2005)

Kandogan, Y.: Evidence for the natural trade partners theory from the Euro-Mediterranean region. Working Paper Series, No. 2005-01, University of Michigan-Flint School of Management (2005)

Kangas, K., Niskanen, A.: Trade in forest products between European Union and the Central and Eastern European access candidates. For. Policy Econ. 5(3), 297-304 (2003)

Kong, T.: China-V4 trade relations 2000-2012 - an overview current trends and perspectives in development of China-V4 trade and investment, pp. 4-23. University of Economics in Bratislava, Faculty of International Relations, Bratislava (2014)

Koopman, R., Wang, Z., Wei, S.-J.: Tracing value-added and double counting in gross exports. Am. Econ. Rev. 104(2), 459-494 (2014)

Liu, Z.: Zhongguo yu Zhongdongou hezuo: wenti yu duice (China-Central and Eastern Europe Cooperation: Problems and Answers), "Guoji Wenti Yanjiu”, no. 5, pp. 73-82 (2013)

Liu, Z.: The analysis of China's investments in V4, current trends and perspectives in development of ChinaV4 trade and investment. Conference Proceedings, University of Economics in Bratislava (2014)

Lu, F., Cheng, Y., Chen, S., Ning, L., Mei, X.: Exploring the upgrading of Chinese automotive manufacturing industry in the global value chain: an empirical study based on panel data. Sustainability 7(5), 6189-6621 (2015)

Marin, D.: A new international division of labor in Europe: outsourcing and offshoring to Eastern Europe. J. Eur. Econ. Assoc. 4, 612-622 (2006) 
Matura, T.: Chinese investment in the EU and central and Eastern Europe. In: Moldicz, C. (ed.) China's Attraction: The Case of Central Europe, pp. 49-72. Budapest Business School, Budapest (2017)

Nilsson, L.: Trade integration and the EU economic membership criteria. Eur. J. Polit. Econ. 16, 807-827 (2000)

OECD/WTO Trade in Value Added Database: (2019). https://stats.oecd.org

Pavlinek, P.: Transformation of the Central and East European passenger car industry: selective peripheral integration through foreign direct investment. In: Turnock, D. (ed.) Foreign direct investment and regional development in East Central Europe and the former Soviet Union. Ashgate, Burlington, pp. 71-102 (2005)

Pomfert, R., Sourdin, P.: Value chains in Europe and Asia: which countries participate? International Economics (2017). https://doi.org/10.1016/j.intenco.2016.11.002

Rynarzewski, T.: Refleksje o dylematach wpływu handlu zagranicznego na rozwój gospodarczy krajów słabo zaawansowanych ekonomicznie. Stud. Oecon. Posnan. 1(1), 69-90 (2013)

Sass, M., Szalavetz, A.: Crisis and upgrading: the case of the Hungarian automotive and electronics sectors. Europe Asia Stud. 65(3), 489-507 (2013)

Simkova, O.: Central and Eastern Europe: moving up the value chain resilience. In: PricewaterhouseCoopers, pp. 18-25 (2013)

Song, W. (ed.): China's Relations with Central and Eastern Europe from "Old Comrades" to New partners. Routledge, London (2017)

Stehrer, R., Stöllinger, R.: The Central European manufacturing core: what is driving regional production sharing? FIW Research Reports 2014/2015 No. 02 (2015)

Stöllinger, R., Hanzl-Weiss, D., Leitner, S., Stehrer, R.: Global and regional value chains: how important, how different? wiiw Research Reports 427, The Vienna Institute for International Economic Studies, wiiw (2018)

Szunomár, A. Chinese investments and financial engagement in Visegrad countries - Myth or reality? Institute for World Economics. Centre for Economic and Regional Studies, Hungarian Academy of Sciences (2014)

Szunomar A., McCaleb A.: Chinese and other east asian foreign direct investment in central and Eastern Europe: motives, location choices and employment approaches. CESifo Forum, 4 (19) (2018)

Timmer, M.P., Los, B., Stehrer, R., De Vries, G.: Fragmentation, incomes and jobs. An analysis of European competitiveness. WIOD Workin Paper 9 (2012)

Tuszynski, R.: Polish perspectives on CE-China $16+1$ cooperation: the unexpected ukrainian factor. Europolity 9(1), 189-190 (2015)

UNCTAD (2019). https://unctad.org/en/Pages/statistics.aspx

Publisher's Note Springer Nature remains neutral with regard to jurisdictional claims in published maps and institutional affiliations. 